\title{
Pengaruh Current Ratio (CR) dan Net Profit Margin (NPM) Terhadap Earning Per Share (EPS) pada PT Agung Podomoro Land Tbk Periode 2010-2019
}

\author{
Rita Satria \\ Fakultas Ekonomi, Universitas Pamulang; doseno1679@unpam.ac.id*
}

\begin{abstract}
Abstrak
Penelitian ini bertujuan untuk mengetahui pengaruh Current Ratio (CR) dan Net Profit Magrin (NPM) terhadap Earning Per Share (EPS) pada PT Agung Podomoro Land Tbk Periode 201O2019. Metode yang digunakan berupa studi analisis deskriptif dengan pendekatan kuantitatif. Analisa data yang digunakan meliputi analisis regresi linier berganda, regrasi linier sederhana uji asumsi klasik, dan Uji hepotesis (uji T dan Uji F). Hasil yang diperoleh secara parsial Current Ratio tidak bepengaruh terhadap Earning Per Share dan Net Profit Margin berpengaruh signifikan terhadap Earning Per Share. Secara simultan Current Ratio dan Net Profit Margin berpengaruh signifikan terhadap Earning Per Share dengan nilai probabilitas sebesar o.oooo74 dan nilai F-statistic 5.576 > dari F.tabel 4,10.
\end{abstract}

Kata Kunci: Current Ratio (CR); Net Profit Magrin (NPM); Earning Per Share (EPS)

\begin{abstract}
This study aims to determine the effect of Current Ratio (CR) and Net Profit Magrin (NPM) on Earning Per Share (EPS) at PT Agung Podomoro Land Tbkfor the 201O-2019 period. The method used is a descriptive analysis study with a quantitative approach. Data analysis used includes multiple linear regression analysis, simple linear regression classical assumption test, and hypothesis test ( $T$ test and $F$ test). The results obtained partially Current Ratio has no effect on Earning Per Share and Net Profit Margin has a significant effect on Earning Per Share. Simultaneously, Current Ratio and Net Profit Margin have a significant effect on Earning Per Share with a probability value of 0.000074 and an F-statistic value of 5,576> from F. table 4.1O.
\end{abstract}

\section{Keywords: Current Ratio; Net Profit Magrin; Earning Per Share}

*) Korespondensi penulis 


\section{PENDAHULUAN}

Sektor properti dan real estate merupakan bagian yang sangat penting di suatu negara. Hal ini dapat dijadikan indikator untuk menganalisis kesehatan perekonomian suatu negara. Brookfield Asset Management merupakan perusahaan manajemen asset asal Kanada memiliki sekitar 37,1 juta meter persegi ruang komersial, atau mengungguli perusahaan investasi real estate global lainnya. Perusahaan ini didirikan pada tahun 1899, sebagai São Paulo Tramway, Light and Power Company oleh William Mackenzie dan Frederick Stark Pearson. Beroperasi seperti dalam konstruksi dan pengelolaan listrik dan infrastruktur transportasi di Brasil.

Pada tahun 2005, setelah 37 tahun, Brascan Corp. diubah namanya menjadi Brookfield Asset Management Inc. Pada tahun 2018, anak perusahaan publik utama Brookfield termasuk Brookfield Infrastructure Partners, Brookfield Renewable Partners, Brookfield Property Partners, dan Brookfield Business

Pada 13 Maret 2019, Brookfield Asset Management mengumumkan bahwa mereka telah setuju untuk membeli sebagian besar Oaktree Capital Management seharga sekitar \$ 4,7 miliar, menciptakan salah satu pengelola uang alternatif terbesar di dunia. Pada tanggal 31 Juli 2019, penjualan Vodafone New Zealand Limited kepada konsorsium yang terdiri dari Infratil Limited dan Brookfield Asset Management Inc. telah diselesaikan. Di antara sejumlah real estate yang memiliki publik selama setahun terakhir, asset terbesar yaitu $\mathrm{Rp} 2.800$ triliun, pendapatan tertinggi Rp 685 triliun, laba tertinggi ketiga $\mathrm{Rp} 33$ triliun, dan pasar tertinggi ketiga $\mathrm{Rp} 560$ triliun. Hasil ini membuat Brookfield tidak hanya perusahaan investasi real estate terbesar di planet ini, tetapi juga peringkat teratas dari tiga perusahaan Kanada dalam daftar Forbes Global 2000 tahun 2018.
Global 2000 adalah peringkat tahunan perusahaan publik terbesar dan terkuat di dunia yang didasarkan pada empat indikator, yakni pendapatan, laba, aset, dan nilai pasar. Daftar tersebut berisi berbagai perusaaan dari 60 negara. Dalam 12 bulan terakhir, perusahaan-perusahaan ini bersama-sama menghasilkan $\mathrm{Rp} 563$ biliun dalam penjualan dan $\mathrm{Rp} 46$ biliun dalam laba. Mereka memiliki total aser Rp 272 biliun dan nilai pasar gabungan sebesar Rp 817 biliun. Investor real estate disebut bukan hanya mengenai jumlah uang yang mereka hasilkan, melainkan juga ruang lingkup dan kualitas properti yang mereka miliki.

Brookfield juga memiliki $\mathbf{1 4 . 2 0 0}$ kamar hotel, termasuk Atlantis di Bahama dan Diplomat di Florida, selain sejumlah pusat perpelanjaan milik divisi Rouse Properties dan General Growth, serta beberapa pusat perpelanjaan terkini di Brasil. Secara keselutuhan, 38 investor real estate membuat daftar Global 2000 tahun ini, tetapi tidak termasuk perusahaan seperti Blackstone. Raksasa ekuitas swasta yang memiliki portofolio properti sangat besar dan berinvestasi dalam berbagai jenis aset. Sebanyak 23 dari 38 perusahaan real estate terbesar di dunia berasal dari Amerika Serikat, empat di antaranya masuk lima besar. Lima perusahaan lainnya berasal dari Australia, disusul Perancis dan Inggris. Daftar 15 perusahaan real estate terbesar di dunia seperti diyunjukkan pada tabel 1 .

Belakangan ini sektor properti diseluruh dunia mengalami penurunan lantaran pembeli yang dianggap prospektif justru menunda transaksinya sampai usia pemilihan umum dan adanya aturan kredit 
Tabel 1. Perusahaan Sektor Properti di Dunia

\begin{tabular}{|c|c|c|c|c|}
\hline No & Nama Perusahaan & $\begin{array}{l}\text { Real estate yang } \\
\text { dimiliki }\end{array}$ & Asset & Nilai Pasar \\
\hline 1. & $\begin{array}{l}\text { Brookfield Asset } \\
\text { Management, Kanada }\end{array}$ & Beragam & Rp 2.807 triliun & Rp. 561 triliun \\
\hline 2. & $\begin{array}{l}\text { American Tower } \\
\text { Corporation, Amerika } \\
\text { Serikat }\end{array}$ & Menara seluler & Rp 498,1 triliun & Rp 882,6 triliun \\
\hline 3. & $\begin{array}{l}\text { Simon Property Group, } \\
\text { Amerika Serikat }\end{array}$ & Ritel & Rp 449,2 triliun & Rp 713 triliun \\
\hline 4. & $\begin{array}{l}\text { Manajemen Modal } \\
\text { Annaly, Amerika Serikat }\end{array}$ & $\begin{array}{l}\text { Utang dan Portofolio } \\
\text { Ekuitas }\end{array}$ & Rp 1,445 triliun & Rp 173 triliun \\
\hline 5 . & Prologis, Amerika Serikat & Gudang & Rp 426,9 triliun & Rp 501,4 triliun \\
\hline 6. & Link REIT, Hongkong & Ritel & Rp 353,4 triliun & Rp 266,5 triliun \\
\hline 7. & $\begin{array}{l}\text { Weyerhaeuser, Amerika } \\
\text { Serikat }\end{array}$ & Perhutanan & Rp 257,3 triliun & $\begin{array}{l}\text { Rp 398, } 5 \\
\text { triliun }\end{array}$ \\
\hline 8. & Klepierre, Perancis & Ritel & Rp 434,2 triliun & Rp 178,1 triliun \\
\hline 9. & Gecina, Perancis & $\begin{array}{l}\text { Perumahan dan } \\
\text { Kantor }\end{array}$ & Rp 347,1 triliun & 183,6 triliun \\
\hline 10. & Westfield, Australia & Ritel & Rp 305,5 triliun & Rp 204,9 triliun \\
\hline 11. & $\begin{array}{l}\text { Public Storage, Amerika } \\
\text { Serikat }\end{array}$ & $\begin{array}{c}\text { Tempat } \\
\text { penyimpanan }\end{array}$ & Rp 153,9 triliun & Rp 530,9 triliun \\
\hline 12. & $\begin{array}{l}\text { Avalonbay communities, } \\
\text { Amerika Serikat }\end{array}$ & Perumahan & Rp 268,5 triliun & Rp 330,7 triliun \\
\hline 13. & $\begin{array}{l}\text { General Growth } \\
\text { Properties (GGP), } \\
\text { Amerika Serikat }\end{array}$ & Ritel & Rp 334,4 triliun & Rp 284,4 triliun \\
\hline 14. & Ventas, Amerika Serikat & Kesehatan & Rp 337,7 triliun & Rp 274,1 triliun \\
\hline 15 . & $\begin{array}{l}\text { Boston Properties, } \\
\text { Amerika Serikat }\end{array}$ & Perkantoran & Rp 281,5triliun & Rp 273,4 triliun \\
\hline
\end{tabular}

Sumber: properti.kompas.com

yang semakin ketat membuat pembiayaan perumahan makin sulit. Berdasarkan data CoreLogic, nilai perumahan turun 0,7\%, dan mencatatkan penurunan $8,2 \%$ dibandingkan dengan periode tahun sebelumnya. Dua kota terbesar di Benua australia masih menjadi pemicu utama penurunan harga rumah secara keseluruhan. Harga rumah di Sydney tercatat turun $0,9 \%$, dan turun $13,9 \%$ dari puncaknya pada pertengahan 2017 lalu. Sementara itu, nilai rumah di Melbourn tercatat turun $0,8 \%$ menjadi $10,3 \%$ di bawah nilai puncaknya. Adapun, secara nasional, laju penurunan harga rumah memang melambat, akan tetapi lokasi penurunan harganya meluas.

PT Agung Podomoro Land Tbk adalah pemilik, pengembang dan pengelola beragam produk dan proyek real estate ritel, komersial dan residensial dengan kepemilikan yang beragam. Perusahaan Agung Podomoro Land Tbk dikenal sebagai pelopor pengembangan superblok. Sebagian dari proyek-proyek penting berkualitas tinggi dari APLN adalah Podomoro City, Green Bay Pluit, Kuningan City, dan Senayan City. Agung Podomoro Land Tbk didirikan pada tanggal 30 Juli 2004 dengan nama PT Tiara Metropolitan Jaya.

Dalam tahun 2010, para pemegang saham perusahaan menuntaskan proyek restrukturisasi perusahaan, dimana dilakukan transfer pengusaan enam pengembang berikut perusahaan induknya. Agung Podomoro Land adalah satu di antara beberapa pengembang real estate dengan perkembangan usaha tercepat dan terbesar di Indonesia, dengan rangkaian produk superblok, properti ritel, perkantoran, apartemen dan residensial, 
dan hotel yang banyak diminati. Untuk mendapatkan investor, PT Agung Podomoro Land Tbk harus menunjukan kinerja perusahaan yang baik salah satunya adalah kinerja dalam aspek keuangan.

Salah satu indikator penting dalam mencapai kinerja suatu perusahaan yang optimal adalah laba (profit). Profitabilitas sering digunakan untuk mengukur efisiensi penggunaan modal dalam suatu perusahaan dengan membandingkan antara laba dan modal yang digunakan dalam operasi. Pemodal yang menginvestasikan dananya pada suatu perusahaan dalam bentuk saham mengharapkan hasil dari pembelian saham tersebut. Pemodal dapat menggunakan profitabilitas suatu perusahaan sebagai alat untuk mengukur modal yang ditanamkan di perusahaan tersebut.

Para investor melakukan penanaman modal dalam perusahaan dengan tujuan untuk mendapat hasil yang sesuai harapannya oleh karena itu sebelum melakukan penanaman modal pihak investor mengevaluasi pendapatan yang diperkirakan akan diperoleh dari investasinya, ini berarti para investor harus melakukan analisis atau laporan keuangan perusahaan yang akan dipilih sebagai tempat penanaman modalnya. Salah satu informasi yang ditentukan pemodal adalah informasi laporan keuangan atau laporan keuangan tahunan. Paling sedikit satu kali dalam setahun perusahaan publik berkewajiban menerbitkan laporan keuangan tahunan kepada para pemodal yang ada di bursa. Informasi akuntansi dapat diperoleh dalam bentuk laporan laba-rugi, neraca, perubahan modal, laporan arus kas, dan catatan atas laporan keuangan.

Investor mempunyai tujuan utama dalam menanamkan dananya ke dalam perusahaan yaitu untuk mencari pendapatan dan laba per saham. Investor mengharapkan laba yang diperoleh perusahaan dapat dikelola baik oleh manajer secara tepat dan optimal demi kepuasan para investor dan demi kelangsungan perusahaan. Laba yang dialokasikan pada laba ditahan akan digunakan kembali perusahaan untuk di investasikan kembali pada aktiva-aktiva yang menguntungkan. Sendangkan laba yang dialokasikan pada dividen akan dibagikan kepada investor.

Beberapa teknik yang dapat digunakan dalam menganalisis data keuangan untuk kebijakan dividen perusahaan diantaranya analisis rasio keuangan. Rasio keuangan dapat digunakan untk mengetahui tingkat likuiditas dan profitabilitas dengan menggunakan current ratio dan net profit margin pada perusahaan, apakah manajemen efektif dalam menghasilkan laba operasi atas aktiva yang dimiliki perusahaan, bagaimana perusahaan didanai, apakah pemegang saham bisa mendapat tingkat pembagian saham yang cukup.

Kinerja keuangan perusahaan merupakan suatu gambaran tentang kondisi keuangan suatau perusahaan yang dianalisis dengan alat-alat analisis keangan dan merupakan alat analisis yang paling, mudah dan murah untuk didapat para investor dan calon investor. Salah satu komponen yang berhubungan dengan kondisi internal perusahaan adalah kinerja perusahaan yang terdiri dari Current Ratio yang mengukur tingkat likuiditas perusahaan dan Net Profit Margin mengukur tingakt profitabilat perusahaan.

Current Ratio merupakan kemampuan perusahan dalam memenuhi atau melunasi kewajiban-kewajiban jangka pendek, dimana bisa diketahui sampai seberapa jauh sebenarnya jumlah aktiva lancar perusahaan bisa menjamin utang lancarnya. Semakin tinggi rasio itu artinya terjamin utang-utang yang dimiliki perusahaan kepada kreditur, begitu juga sebaliknya. Jika rasio lancarnya semakin 
tinggi, maka semakin tinggi pula likuiditas suatu perusahaan.

Net Profit Margin merupakan rasio profitabilitas, rasio ini digunakan untuk menunjukan kemampuan perusahaan dalam menghasilkan keuntungan bersih setelah dipotong pajak. Net Profit Margin sama dengan laba bersih dibagi dengan penjuala bersih. Hal ini menunjukan kestabilan kesatuan untuk menghasilkan perolehan pada tingkat penjualan khusus. Dengan memriksa Net Profit Margin dan norma industri sebuah perusahaan pada tahun-tahun sebelumnya, kita dapat menilai efisiensi operasi dan strategi penetapan harga serta status persaingan perusahaan lain dalam industri.

Namun dalam berinvestasi di pasar modal tidak lepas dari resiko, oleh karena itu investor harus memerlukan sebuah indikator yang cukup baik dalam mengambil keputusan sebelum berinvestasi. Salah satu indikator tersebut adalah Earnig Per Share. Para calon pemegang saham tertarik dengan Earning Per share yang besar, karena hal ini merupakan salah satu indikatot keberhasilan perusahaan. Earnig Per Share menunjukan seberapa besar kemampuan perusahaan untuk memberikan pengembalian (return) kepada pemilik perusahaan. Besarnya Earning Per Share ini dapat diharapkan akan mampu mempengaruhi tingkat kepercayaan para investor dalam berinvestasi. Namun dalam memprediksi Earning Per Share kedepan diperlukan sebuah alat analisis untuk mengetahui informasi keuangan yang dihasilkan bermanfaat untuk mengetahui perkembangan Earning Per Share. Salah satu alat analisis tersebut adalah analisis rasio keuangan. Rasio dalam analisis laporan keuangan merupakan angka yang menunjukan hubungan antara suatu unsur dengan unsur lainnya dalam laporan keuangan. Ada beberapa jenis rasio keuangan yang bisa digunakan untuk mempengaruhi Earnig Per Share. Dalam penelitian ini digunakan rasio keuangan Likuiditas berupa Current Ratio dan Rasio Profitabilitas berupa Net Profit Manrgin.

Data empiris mengenai variabel yang digunakan dalam penelitian ini dapat dilihat pada tabel 2.

Tabel 2. Perbandingan Rasio CR, NPM dan EPS PT Agung Podomoro Land Tbk

\begin{tabular}{|c|c|c|c|}
\hline Tahun & CR & NPM & EPS \\
\hline 2010 & 300,1 & 14,5 & 19,4 \\
\hline 2011 & 182,9 & 17,9 & 28,3 \\
\hline 2012 & 156,6 & 17,9 & 39,6 \\
\hline 2013 & 167,9 & 18,9 & 41,45 \\
\hline 2014 & 183,2 & 18,5 & 41,54 \\
\hline 2015 & 138,9 & 18,7 & 41,53 \\
\hline 2016 & 106,8 & 16 & 33,72 \\
\hline 2017 & 130,6 & 26,6 & 70,25 \\
\hline 2018 & 105,6 & 4,9 & 1,52 \\
\hline 2019 & 166,4 & 0,19 & 0,04 \\
\hline \multicolumn{2}{|l|}{ Sumber : Annual ReportPT. Agung Podomoro Land }
\end{tabular}
Tbk

Dari data dapat diketahui pergerakan Current Ratio dan Net Profit Margin pada perusahaan PT Agung Podomoro Land Tbk tersebut selalu mengalami perubahan setiap tahunnya baik menunjukan peningkatan maupun penurunan dalam kurun waktu selama 10 (sepuluh) tahun terakhir. Hal tersebut menunjukan bahwa adanya pengaruh indicator keuangan terhadap Earning Per Share perusahaan.

Peneliti ini untuk mengkaji "Pengaruh Current Ratio (CR) Dan Net Profit Margin (NPM) Terhadap Earning Per Share (EPS) Pada PT Agung Podomoro Land Tbk Periode 2010-2019"

\section{Rasio Keuangan}

Rasio keuangan merupakan suatu perhitungan rasio dengan menggunakan laporan keuangan yang berfungsi sebagai alat ukur dalam menilai kondisi keuangan dan kinerja perusahaan. Rasio keuangan adalah angka yang diperoleh dari hasil perbandingan antara satu pos laporan 
keaungan dengan pos lainnya yang mempunyai hubungan yang relevan dan signifikan. Perbandingan dapat dilakukan antara satu pos dengan pos lainnya dalam satu laporan keuangan atau antar pos yang ada diantara laporan keuangan (Hery, 2016:138)

Menurut Munawir (2010:64) analisa rasio seperti halnya alat-alat analisa yang lain adalah "Future oriented", oleh karena itu penganalisa harus mempu untuk menyesuaikan faktor-faktor yang ada pada periode atau waktu ini dengan faktorfaktor di masa yang akan datang yang mungkin akan mempengaruhi posisi keuangan atau hasil operasi perusahaan yang bersangkutan. Dengan demikian kegunaan atau manfaat suatu angka rasio sepenuhnya tergantung kepada kemampuan atau kecerdasan penganalisa dalam menginterpretasikan data yang bersangkutan.

\section{Hipotesis}

Hipotesis dalam penelitian ini adalah:

1. $\mathrm{H}_{1}$ : Diduga Current Ratio (CR) berpengaruh terhadap Earning Per Share (EPS) pada PT Agung podomoro Land Tbk Periode 2010-2019.

2. $\mathrm{H}_{2}$ : Diduga Net Profit Margin (NPM) berpengaruh terhadap Earning Per
Share (EPS) pada PT Agung Podomoro Land Tbk Periode 2010-2019.

3. $\mathrm{H}_{3}$ : Diduga Current Ratio (CR) dan Net Profit Margin (NPM) secara bersamasama berpengaruh terhadap Earning Per Sahre (EPS) pada PT Agung Podomoro Land Tbk Periode 20102019.

\section{METODE}

Penelitian ini merupakan penelitian deskriptif kualitatif dengan meneliti data skunder berupa laporan keuangan yang tercatat dalam Bursa Efek Indonesia PT Agung Podomoro Land Tbk berkantor di APL Tower, Podomoro City, Jl. Letjen S. Parman No.Kav. 28, RT.33/RW5, Tj. Duren Sel. Kec. Grogol Petamburan, Kota Jakarta Barat periode 2010-2019. Data tersebut kemudian dianalisa dan di kelompokkan berdasarkan variabel penelitian.

\section{HASIL DAN PEMBAHASAN Hasil Analisis Data Statistic}

Deskripsi data statistik seluruh variabel yang digunakan dalam penelitian ini ditunjukan dalam tabel berikut ini:

\section{Tabel 3.Deskripsi Data Statistik}

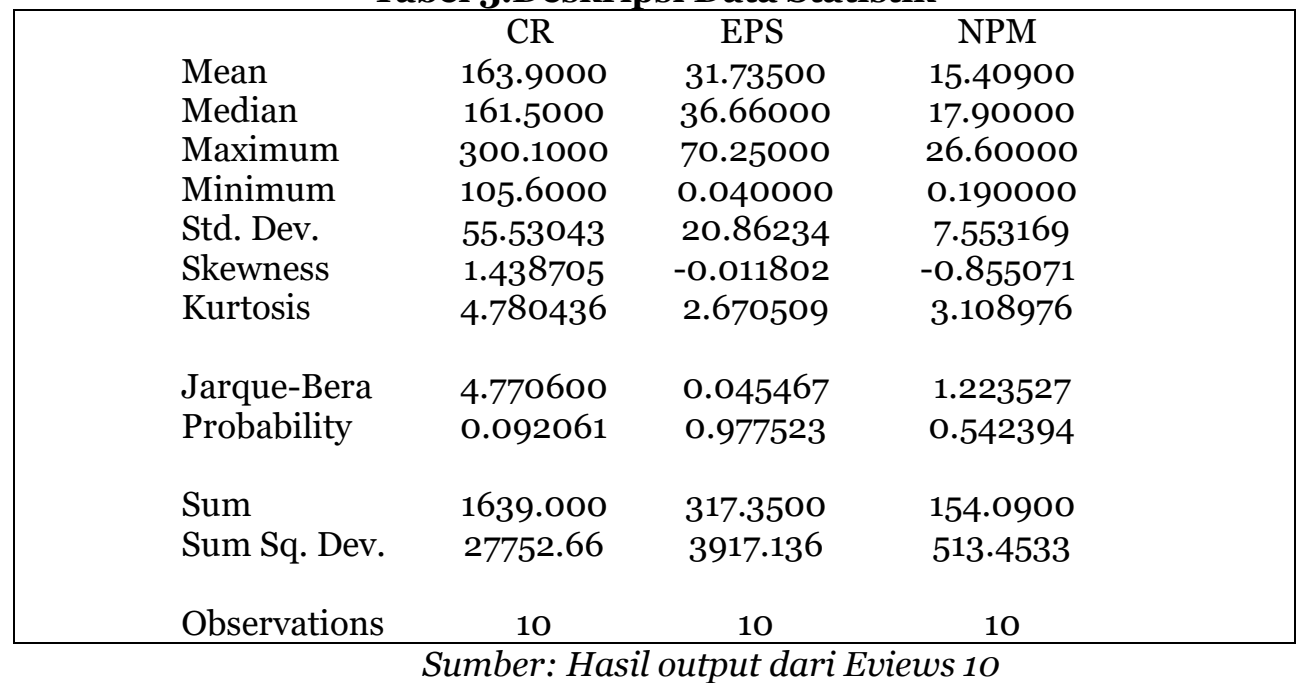


Berdasarkan data pada tabel dapat dijelaskan bahwa dari perusahaan sampel dengan menggunakan metode pooled dimana 1 perusahaan dikalikan periode tahun pengamatan (10 tahun), sehingga sampel dalam penelitian ini menjadi $1 \times 10$ $=10$ sehingga sampel yang digunakan sejumlah 10, rata-rata CR selama periode pengamatan (2010-2019) sebesar 1639.000.

Deskripsi data statistik terdiri dari mean, median, maximum, minimum, standard deviation, skewness, kurtoris, dan statistic Jarque-Berra serta p-value. Nilai mean, median, maximum dan minimum untuk setiap variabel yang digunakan dalam penelitian memiliki angka yang berbeda, tetapi angka tertinggi dari ketiga indikator dialami oleh variabel Current ratio (CR).

Standar deviasi sebagai ukuran untuk mengukur dispersi atau penyebaran data menunjukan angka yang berfluktuasi. Nilai standar deviasi terbesar terdapat di variabel Current Ratio (CR) yaitu sebesar 55,53043 yang berarti bahwa variabel Current Ratio (CR) memiliki tingkat risiko yang lebih tinggi dibandingkan dengan variabel-variabel lain. Sementara variabel yang mempunyai tingkat risiko paling rendah yaitu Net Profit Margin (NPM) sebesar 7.553169 yang menunjukan bahwa NPM selama periode penelitian mengalami perubahan yang tidak terlalu fluktuatif.

\section{Uji Asumsi Klasik}

Uji Multikolineritas, bertujuan untuk menguji apakah dalam suatu model regresi ditemukan adanya antar variabel bebas (independen variabel. Model regresi yang baik seharusnya tidak terjadi korelasi di antara varabel bebas, karena jika hal tersebut terjadi maka variabel-variabel tersebut tidak orthogonal atau terjadi kemiripan.

Untuk mendeteksi apakah terjadi problem multikolinearitas dapat melihat nilai Tolerance dan lawannya Variance Inflation Factor (VIF). Apabila nilai VIF kurang dari 10 dan nilai Tolerance lebih dari 0,1 maka di nyatakan tidak terjadi multikolinearitas. Apabila nilai VIF dari suatu variabel melebihi 10 dan hal ini akan terjadi bila $\mathrm{R}^{2}$ melebihi o,90 maka variabel tersebut dikatakan berkorelasi sangar tinggi (kolinier).

\section{Tabel 4. Hasil Uji Multikolinearitas}

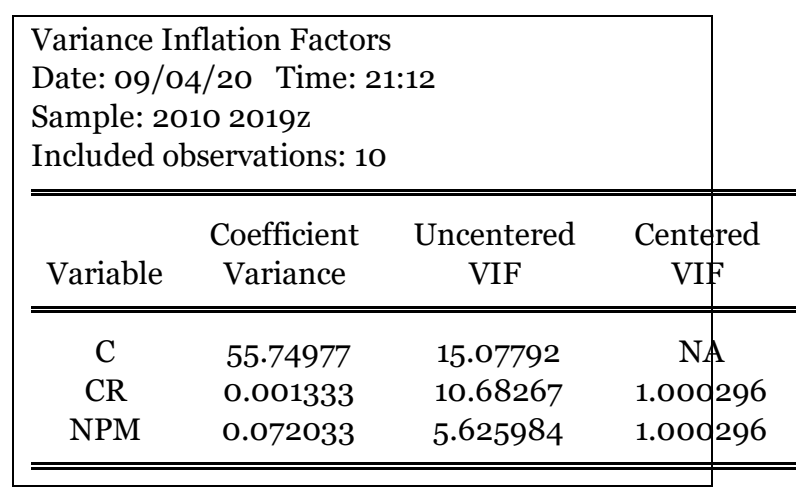

Sumber: Hasil Output Data Linier Berganda Eviews 10

Hasil uji multikolinieritas, dapat dilihat pada tabel 4.6 kolom centered VIF. Nilai VIF untuk variabel yang mempengaruhi Earning Per Share dengan nilai dibawah 10. Karena nilai VIF dari kedua variabel dibawah 10 maka dapat dikatakan tidak terjadi multikolinieritas.

Uji Autokorelasi, untuk melihat apakah terjadi korelasi antara suatu periode $t$ dengan periode sebelumnya $(t-1)$.umunya terjadi pada data time series. Ada beebrapa cara untuk mendeteksi gejala autokorelasi yaitu dengan menggunakan Durbin Watson (DW test).

\section{Tabel 5. Hasil Uji Autokorelasi}

Dependent Variable: EPS

Method: Least Squares

Date: 09/04/20 Time: 20:10

Sample: 20102019 


\begin{tabular}{|c|c|c|c|c|}
\hline \multicolumn{5}{|c|}{ Included observations: 10} \\
\hline Variable & Coefficient & Std. Error & t-Statistic & Prob. \\
\hline $\mathrm{C}$ & 1.142680 & 7.466577 & 0.153039 & 0.8827 \\
\hline $\mathrm{CR}$ & -0.061412 & 0.036506 & -1.682241 & 0.1364 \\
\hline NPM & 2.638568 & 0.268389 & 9.831137 & 0.0000 \\
\hline R-squared & 0.933926 & \multicolumn{2}{|c|}{ Mean dependent var } & 31.73500 \\
\hline Adjusted R-squared & 0.915048 & \multicolumn{2}{|c|}{ S.D. dependent var } & 20.86234 \\
\hline S.E. of regression & 6.080661 & \multirow{2}{*}{\multicolumn{2}{|c|}{ Akaike info criterion }} & 6.691429 \\
\hline Sum squared resid & 258.8211 & & & 6.782204 \\
\hline Log likelihood & -30.45714 & \multicolumn{2}{|c|}{ Hannan-Quinn criter. } & 6.591848 \\
\hline F-statistic & 49.47086 & \multirow{2}{*}{\multicolumn{2}{|c|}{ Durbin-Watson stat }} & 2.526386 \\
\hline Prob(F-statistic) & 0.000074 & & & \\
\hline
\end{tabular}

Sumber: Hasil Output Data Linier Berganda Eviews 10

Hasil uji autokorelasi DurbinWatson memperlihatkan nilai statistic Durbin-Watson (DW) sebesar 2.526386 angka ini (du) 1.6413 dan (4-du) 4-1.6413 = 2.3587 maka koefisien autokorelasi sama dengan nol, berarti tidak ada masalah autokorelasi.

Uji Normalitas, adalah untuk melihat apakah nilai residual terdistribusi normal atau tidak. Model regresi yang baik adah memiliki nilai residual yang terdistrubusi normal. Pengujian terhadap residual terdistribusi normal atau tidak dapat menggunakan jerque-bera test. Apabila nilai Prob JB hitung lebih besar dari nilai tingkat alpha maka dapat disimpulkan bahwa residual terdistribusi normal dan sebaliknya. Nilai Sig > 0,05 menunjukkan bahwa data dalam penelitian berdistribusi normal.

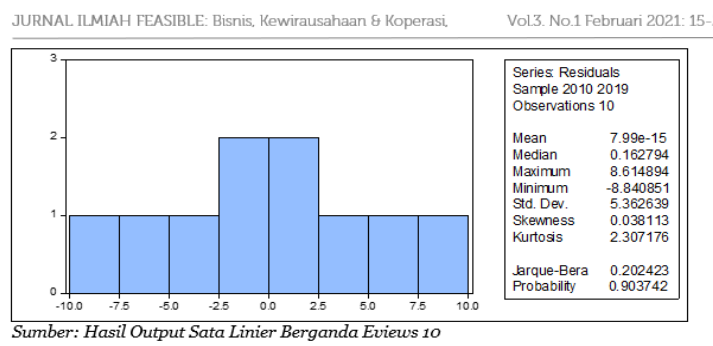

Gambar 1. Hasil Uji Normalitas
Hasil uji normalitas dapat dilihat bahwa JB (jerque-bera) hitung sebesar 0.202423 dan nilai Prob sebesar 0.903742 lebih besar dari 0,05 (5\%) sehingga dapat disimpulkan bahwa residual terdistribusi normal yang artinya asumsi klasik tentang kenormalan telah dipenuhi.

Uji Heteroskedastisitas, bertujuan menguji apakah dalam model regresi terjadi ketidaksamaan variance dari residual satu pengamatan ke pengamatan lain. Model regresi yang baik yaitu tidak terjadi heteroskedatisitas. Keputusan terjadi atau tidaknya heteroskedatisitas pada model regresi linier adalah dengan melihat nilai Prpb. F-statistic (F hitung). Apabila nilai Prob. F hitung lebih besar dati tingkat aplha 0,05 (5\%) maka Ho diterima yang artinya tidak terjadi heteroskedastisitas, sedangkan apabila nilai Prob. $\mathrm{F}$ hitunglebih kecil dari tingkat alpha 0,05 (5\%) maka Ho ditolak yang artinya terjadi heteroskedastisitas

\section{Tabel 6. Hasil Uji Heteroskedastisitas}

Heteroskedasticity Test: Breusch-Pagan-Godfrey

\begin{tabular}{llll}
\hline \hline F-statistic & 0.580240 & Prob. F(2,7) & 0.5846 \\
\hline
\end{tabular}




\begin{tabular}{|c|c|c|c|c|}
\hline $\begin{array}{l}\text { Obs*R-squared } \\
\text { Scaled explained SS }\end{array}$ & $\begin{array}{l}1.422074 \\
0.455431\end{array}$ & \multicolumn{2}{|c|}{$\begin{array}{l}\text { Prob. Chi-Square(2) } \\
\text { Prob. Chi-Square(2) }\end{array}$} & $\begin{array}{l}0.4911 \\
0.7964\end{array}$ \\
\hline \multicolumn{5}{|c|}{$\begin{array}{l}\text { Test Equation: } \\
\text { Dependent Variable: RESID^2 } \\
\text { Method: Least Squares } \\
\text { Date: o9/04/20 Time: } 22: 32 \\
\text { Sample: } 2010 \text { 2019 } \\
\text { Included observations: } 10\end{array}$} \\
\hline Variable & Coefficient & Std. Error & t-Statistic & Prob. \\
\hline $\begin{array}{c}\mathrm{C} \\
\mathrm{CR} \\
\mathrm{NPM}\end{array}$ & $\begin{array}{r}60.30676 \\
-0.073624 \\
-1.450947\end{array}$ & $\begin{array}{l}40.22347 \\
0.196662 \\
1.445848\end{array}$ & $\begin{array}{r}1.499293 \\
-0.374369 \\
-1.003527\end{array}$ & $\begin{array}{r}0.1775 \\
0.7192 \\
0.3490\end{array}$ \\
\hline $\begin{array}{l}\text { R-squared } \\
\text { Adjusted R-squared } \\
\text { S.E. of regression } \\
\text { Sum squared resid } \\
\text { Log likelihood } \\
\text { F-statistic } \\
\text { Prob(F-statistic) }\end{array}$ & $\begin{array}{r}0.142207 \\
-0.102876 \\
32.75735 \\
7511.309 \\
-47.29729 \\
0.580240 \\
0.584572\end{array}$ & \multicolumn{2}{|c|}{$\begin{array}{l}\text { Mean dependent var } \\
\text { S.D. dependent var } \\
\text { Akaike info criterion } \\
\text { Schwarz criterion } \\
\text { Hannan-Quinn criter. } \\
\text { Durbin-Watson stat }\end{array}$} & $\begin{array}{r}25.88211 \\
31.19216 \\
10.05946 \\
10.15023 \\
9.959876 \\
2.399695\end{array}$ \\
\hline
\end{tabular}

Sumber : Hasil Output Data Linier Berganda Eviews 10

Hasil uji heteroskedastisitas diperoleh nilai Prob. F hitung $(2,7)$ sebesar 0.5846 lebih besar dari tingkat alpha 0,05 (5\%), artinya tidak terjadi heteroskedastisitas.

\section{Pembahasan}

Hasil uji t (parsial) diperoleh nilai prob.t hitung dari Current Ratio (CR) sebesar 0.6852 yang lebih besar dari 0.05 dan nilai t Statistic $0.420455<$ dari tabel 2.22814 berarti variabel bebas Current Ratio terhadap Earning Per Share pengaruhnya tidak signifikan terhadap Earning Per Share (EPS) pada PT Agung Podomoro Land Tbk.

Hasil uji parsial pengaruh net profit margin terhadap earning per share diperoeh nilai prob.t hitung sebesar 0.0000 yang lebih kecil dari 0.05 dan nilai t-Statistic 8.844189 > dari tabel 2.22814, artinya Net Profit Margin (NPM) secara parsial berpengaruh positif dan signifikan terhadap Earning Per Share (EPS) pada PT Agung Podomoro Land Tbk.
Hasil uji simultan pengaruh current ratio dan net profit margin terhadap earning per share diperoleh nilai prob.(F.statistic) sebesar 0.000074 lebih kecil dari tingkat signifikan yaitu 0.05 dan F-statistic 5.575928 > dari F.tabel 4,10. Dapat disimpulkan bahwa model regrasi yang diestimasi terdapat pengaruh antara Current Ratio (CR) dan Net Profit Margin (NPM) terhadap Earning Per Share (EPS) pada PT Agung Podomoro Land Tbk.

\section{SIMPULAN}

Berdasarhasil hasil dan pembahasan dapat disimpulkan:

Current Ratio (CR) berpengaruh negatif dan tidak signifikan secara parsial terhadap Earning Per Share (EPS) pada PT Agung Podomoro Land Tbk periode 20102019.

Net Profit Margin (NPM) berpengaruh positif dan signifikan terhadap Earning Per Share (EPS) pada PT Agung Podomoro Land Tbk periode 2010-2019.

Current Ratio (CR) dan Net Profit Margin (NPM) secara simultan ber- 
pengaruh positif dan signifikan terhadap Earning Per Share (EPS) pada PT Agung Podomoro Land Tbk periode 2010-2019. dengan nilai Prob.(F.statistic) $0.000074<$ 0.05 dan F-statistic 5.576 > F.tabel 4,10.

Keterbatasan penelitian ini hendaknya dapat disempurnakan dan dikembangkan dengan menambah beberapa hal pada penelitian lanjutan diantaranya: populasi penelitian, jumlah sampel yang digunakan, menambah data atau periode pengamatan yang digunakan, sehingga dapat terjabarkan lebih baik keadaan yang sebenarnya.

\section{DAFTAR PUSTAKA}

Agus, Widarjono. (2007). Ekonometrika Teori dan Aplikasi. Yogyakarta: Ekonisia.

Brigham, E.F dan Houston, J.F. (2013). Dasar-dasar Manajemen Keuangan Buku 1 Edisi 10. Jakarta. Salemba Empat.

Danim, Sudarwan, dan Yunan Danim. (2010). "Adminsitrasi \& Manajemen”. Bandung: Pustaka Setia.

Fahmi, Irham. (2014).Analisa Laporan Keuangan. Bandung : Alfabeta.

Gujarati, Damodar. (2003). Ekonometri Dasar. Terjemahan: Sumarno Zain. Jakarta: Erlangga.

Hasibuan, Melayu. (2012). "Manajemen Sumber Daya Manusia”. Jakarta: PT Bumi Aksara.

Hasibuan, Melayu S. P. (2016). Manajemen Sumber Daya Manusia. Jakarta: PT Bumi Aksara.

Husnan, Suad. (2012). Dasar-Dasar Manajemen Keuangan.: UPP STIM YKPN

Hery. (2016). Analisis Laporan Keuangan. Jakarta: Grasindo

Harahap, Sofyan Syafri. (2007). Analisis Kritis Atas Laporan Keuangan, Cetakan ke-7. Jakarta: PT Raja Grafindo Persada.
Harjito, D.A dan Martono. (2014). Manajemen Keuangan. Edisi Kedua. Yogyakart: EKONOSIA. Kampus Fakultas Ekonomi Islam Indonesia.

Imam, Ghozali. Imam. (2018). "Analisis Multivariat dan ekononetrika Eviews 10". Semarang: Badan Penerbit Undip.

Kasmir, (2010). "Pengantar Manajemen Keuangan” Jakarta : Kencana Prenda Media Group.

Kasmir. (2013), "Analisis Laporan keuangan". Jakarta: PT. Raja Grafindo Persada.

Kasmir. (2015). Analisis Laporan Keuangan. Jakarta : PT Raja Grafindo Persada.

Munawir, S. (2010). Analisa Laporan Keuangan. Yogyakarta : Liberty.

Robbins, Stephen P. dan Colter, Mary. Manajemen (edisi kesepuluh). Jakarta : Erlangga.

Riyanto. (2012). Dasar-dasar Pembelajaran. Edisi 4 Yogyakarta: BPFE.

Solihin, Ismail. (2009). Corporate Social Responsibility from Charity to Sustainability. Jakarta : Salemba Empat.

Terry, George R. dalam Afifudin. (2013). Dasar-dasar Manajemen, (Terje: G.A Ticoalu), CV. Alfabeta, Bandung. Sugiyono. (2017). Metode Penelitian Kuantitatif, Kualitatif, dan $R \& D$. Bandung : Alfabeta, CV

Duci, Welas. (2016)."Pengaruh Current Ratio (CR), Debt To Equity Tatio, Net Profit Margin (NPM) dan Total Asset Turnover Terhadap Earning Per Share (Studi Empiris Pada Perusahaan Publik Sub Sektor Kimia Periode 2011-2015”

Pardede, Siska Dora Yulianti. (2018). “ Pengaruh return On Asset (ROA), Return On Equity (ROE), dan Earning Per Share (EPS) Terhadap Harga Saham Pada PT. Bank Central Asia. Tbk Periode Tahun 2012-2017" UNPAM. 
Dianita, Fatrus. (2018)."Pengaruh Return On Asset (ROA) dan Return On Equity (ROE) Terhadap Earning Per Share (EPS) Pada PT. Nippon Indosari Corpindo Tbk Tahun 20092017". UNPAM.

Rahmawati, Dhiyah. (2016).” Pengaruh Net Profit Margin (NPM) dan Return On Asset (ROA) Terhadap Harga Saham PT. Adtra Argo Lestari Tbk Tahun 2006-2015" UNPAM.

Kurnia, Yoga Dwi. (2017). "Pengaruh Current Ratio (CR). Net Profit Margin (NPM), dan Earning Per Share (EPS) terhadap Harga Saham (Studi kasus Perusahaan transportasi yang terdaftar di BEI periode tahun 2011-2016"

Putri, Novia Kasyaretta Ananda. (2018)."Analisis Pengaruh ROA, ROE,NPM, dan EPS terhadap Harga Saham )Studi Kasus pada Perusahaan Sektor Properti Sub Residence yang Listing di Bursa Efek indonesia Periode 2014-2016)"

Serlita, Yuningsih. (2018).”Pengaruh Current Ratio dan Return On Equity terhadap Harga Saham pada Bank Negara Indonesia pada Tahun 2008-2017" UNPAM.

Juniati, Winda. (2018). "Pengaruh Net Profit Margin (NPM) dan Debt To Equity Ratio (DER) Tergadap Harga Saham (Studi Kasus) PT. Mandom Indonesia" UNPAM.

Prasetyo, Mardani. (2017). "Pengaruh Current Ratio dan earning Per Share terhadap Harga Saham pada Perusahaan Makanan dan Minuman Periode 2012-20124 yang Terdaftar di Bursa Efek indonesia (BEI)" UNPAM.

Fransisca, Fatricia. (2018)."Pengaruh Earning Per Share (EPS) dan Return On Asset (ROA) Terhadap Return
Saham pada PT Bank BTN, Tbk Tahun 2007-2016" UNPAM.

Satria, Rita. (2017). "Analisis Laporan Keuangan untuk Melihat Kinerja Perusahaan pada PT Dharma Henwa Tbk Periode 2012-2016" Jurnal Sekuritas. Vil.1.No.2, Desember 2017. 